\title{
Moderate acute malnutrition prevention with a ready-to-use supplementary food in pre-school children from rural communities
}

\author{
Juan O. Talavera, ${ }^{1 *}$ Mónica J. García-Vilchis, ${ }^{2}$ Thanya S. Labrada-Alba, ${ }^{3}$ Fabián Olvera-Flores, ${ }^{3}$ \\ María F. Martínez-Jaureguiberry² and Brenda Salgado-Enríquez ${ }^{2}$ \\ ${ }^{1}$ Directorate of Teaching and Research, Centro Médico ABC; ${ }^{2}$ Global R\&D Life Sciences, Nutrition Sciences, PepsiCo Inc.; ${ }^{3}$ Division of Operations, \\ Monitoring and Evaluation, Un Kilo de Ayuda A.C. Mexico City, Mexico
}

\begin{abstract}
Introduction: Child malnutrition in Mexico reaches a prevalence as high as $27.5 \%$ in rural areas. Objective: To assess the effectiveness of a ready-to-use supplementary food (RUSF) to correct mild acute malnutrition and prevent moderate acute malnutrition in preschool children from rural communities. Method: Randomized clinical trial, with assignment to two groups: group with RUSF (RUSF-g) or group without it (non-RUSF-g); children aged from two to five years, with weight-for-height Z-scores (WHZ) between -2 and -1 and low socioeconomic status were included. All received education on nutrition, health and hygiene twice monthly; the RUSF-g children had to consume one portion of the supplement every day. WHZ was assessed at baseline and at four, six, and 12 months. The comparison between groups was carried out with Cox proportional hazards model. Results: With regard to mild acute malnutrition correction in the RUSF-g, 68.7 versus $52.1 \%$ in the control group was observed in the intent-to-treat analysis, with a hazard ratio $(H R)=1.25$; in the per-protocol analysis of first semester, a $H R=$ 1.48 was observed, and in the second semester, $H R=1.56$. One patient progressed to moderate acute malnutrition. Conclusions: The RUSF-g showed a significantly higher resolution of mild acute malnutrition.
\end{abstract}

KEY WORDS: Supplementary food. Moderate malnutrition. Prevention program.

\section{Prevención de desnutrición aguda moderada con un suplemento alimenticio listo para consumir en niños preescolares de comunidades rurales}

\section{Resumen}

Introducción: La desnutrición infantil en México alcanza prevalencias de $27.5 \%$ en zonas rurales. Objetivo: Evaluar la efectividad de un suplemento alimenticio listo para consumir (SALC) para corregir desnutrición aguda leve y prevenir desnutrición aguda moderada en preescolares de comunidades rurales. Método: Ensayo clínico aleatorizado por grupos: con y sin SALC (g-SALC y g-S/SALC); se incluyeron niños de dos a cinco años, con puntuaciones-Z de peso para la talla (pZ-P/T) mayor de -2 y menor de -1 y nivel socioeconómico bajo. Todos recibieron educación sobre nutrición, salud e higiene dos veces al mes; los niños del g-SALC debieron consumir diariamente una porción del suplemento. Se evaluó pZ-P/T al inicio y a los cuatro, seis y 12 meses. La comparación entre grupos se realizó con el modelo de riesgos proporcionales de Cox. Resultados: Respecto a la recuperación de desnutrición aguda leve, en g-SALC se observó 68.7 versus $52.1 \%$ en el grupo control en el análisis de intención para tratar, con una razón de riesgo $(H R)=1.25$; en el análisis por protocolo del primer semestre se observó una $H R=1.48$ y en el segundo semestre, $H R=1.56$. Un paciente progresó a desnutrición aguda moderada. Conclusiones: El g-SALC mostró resolución significativamente mayor de desnutrición aguda leve.

PALABRAS CLAVE: Suplemento alimenticio. Desnutrición moderada. Programa de prevención.

Correspondence:

*Juan O. Talavera

E-mail: jotalaverap@abchospital.com
Gac Med Mex. 2020;156:499-508 Contents available at PubMed www.gacetamedicademexico.com 0016-3813/@ 2020 Academia Nacional de Medicina de México, A.C.. Published by Permanyer. This is an open access article under the CC BY-NC-ND license (http://creativecommons.org/licenses/by-nc-nd/4.0/). 


\section{Introduction}

Undernourishment is mainly due to insufficient protein and micronutrient intake., ${ }^{1,2}$ There are around 821 million people with undernourishment in the world. ${ }^{3}$ It is the main cause of failure to thrive, short stature and cognitive deficit, ${ }^{4}$ and in developing countries, it is associated with $60 \%$ of child mortality. ${ }^{4,5}$ Among the micronutrient deficiencies, iron deficit is the most prevalent. ${ }^{6-16}$ In Mexico, $4.4 \%$ of the population is in extreme poverty and $20 \%$ lives below minimum well-being levels. ${ }^{17}$ Mexico has managed to reduce undernourishment from $26.9 \%$ in 1988 to $15.5 \%$ in $2006 .^{18}$ The ENSANUT survey recorded that, from 2006 to 2012, weight-for-height z-scores (WHZ) in children younger than 5 years went from 2 to $1.6 \%$, from 3.4 to $2.8 \%$ in the case of weight-for-age (WAZ), and from 15.4 to $13.6 \%$ in that of height-for-age (HAZ). In Mexico, food insecurity affects $18.2 \%$ of the population, with figures as high as $47 \%$ in Chiapas, $42 \%$ in Guerrero and $38 \%$ in Oaxaca, mainly in rural localities. , $^{17,19-21}$

In children with moderate acute malnutrition, supplementary foods produce an average increase in the recovery rate of nearly $30 \%(0.28)$; however, when these foods are withdrawn, relapse rates reach $50 \%$ within the first year. ${ }^{22,23}$ The longer the intervention time, the higher the probability of maintaining the benefit. ${ }^{24}$ Similarly, supplemental nutrition prevents the progression from mild to moderate acute malnutrition. ${ }^{25}$ Consequently, standardized programs that include dietary supplements are recommended for the treatment of malnutrition. ${ }^{26}$

The present study had the purpose to prevent the appearance of moderate acute malnutrition ( $\mathrm{WHZ}>-3$ and $\leq-2)$ and to mitigate mild acute malnutrition (WHZ > -2 and <-1) in preschool children in rural areas of Mexico, through a strategy with nutritional supplements supplied over a 12-month period.

\section{Method}

Controlled trial of rural communities that were randomized in groups to receive or not a ready-to-use supplementary food (RUSF): RUSF-g and nonRUSF-g, respectively. Twice monthly, all individuals received education on nutrition, health and hygiene; the RUSF-g had to consume one daily RUSF serving in the form of four biscuits. Randomization was performed with computer-generated random numbers.
The study was carried out in Oaxaca (Salina Cruz, Miahuatlán and Pinotepa), Chiapas, Yucatán and the State of Mexico. Children aged between two and five years, belonging to the lowest socioeconomic level (classes $\mathrm{E}$ and $\mathrm{D}$ out of seven strata), who resided in rural areas, with $\mathrm{WHZ}>-2$ and $<-1$, whose parents or legal guardians granted informed consent to participate, were selected. Children with severe or moderate malnutrition ( $\mathrm{WHZ}<-2),{ }^{26}$ vitamin A deficiency (indicated by softening, ulceration or cloudiness of the cornea and dryness of the conjunctiva), iodine deficiency (indicated by visible goiter), acute infection, including diarrhea ( $\geq 3$ liquid stool episodes/day, lasting $>24$ hours), fever for $>24$ hours, respiratory infection (cough and/or rhinorrhea for $>24$ hours), current consumption of other dietary supplement, known allergy to peanuts or biscuit ingredients in the child or a direct relative, were excluded. All children detected with severe acute malnutrition $(\mathrm{WHZ}<-3)$ or disease were referred to health clinics or hospitals for treatment and were given iron supplementation in case of anemia (Fig. 1).

Participants were able to withdraw from the study at any point in time. Children who developed moderate malnutrition $(\mathrm{WHZ}<-2)$ during the research continued to receive the dietary supplement and education on nutrition, health, and hygiene, in addition to being referred to health clinics.

In both groups, each parent or legal guardian attended a nutrition, health and hygiene education program. This program included 24 face-to-face practical sessions in which a trained facilitator, using printed materials and visual activities, shared information with the parents. Twelve different topics that were relevant to the region were defined, with information on each subject being provided in two 20-minute sessions every 14 days. The topics and their objectives are described in Appendix 1.

\section{Ready-to-use supplementary food}

Each child belonging to the RUSF group (RUSF-g) received one serving of biscuits every day for 12 months. Parents or legal guardians were instructed to provide the RUSF-g children with two half servings a day, as a snack between meals, to achieve the consumption of a total serving of four biscuits per day, which is equivalent to $250 \mathrm{kcal}, 6 \mathrm{~g}$ of protein, $12 \mathrm{~g}$ of lipids and $29.5 \mathrm{~g}$ of carbohydrates. The biscuits were formulated with nutrient-rich foods such as oats, peanuts, milk, and eggs, and were also enriched with 


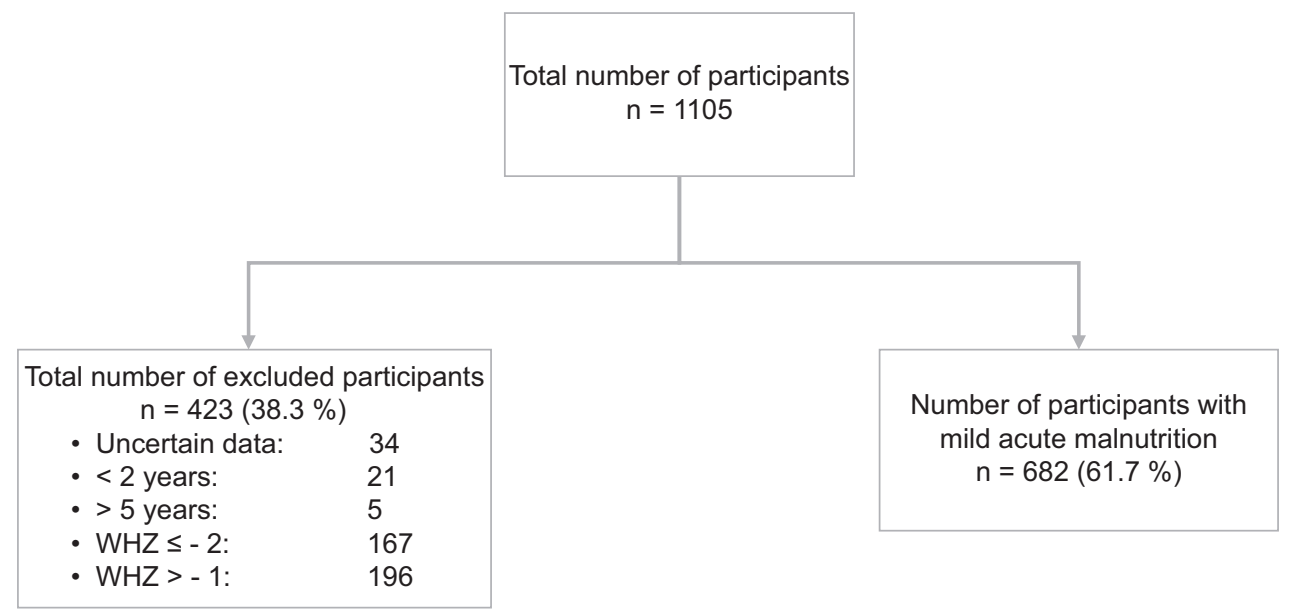

Figure 1. Flowchart for the selection of participants.

vitamins and inorganic nutrients (Appendix 2). Since the dietary supplement is designed to complement the family meal, parents or legal guardians were instructed not to replace any portion of the child's normal food, who should receive three meals a day as usual. ${ }^{27}$ In order for the dietary supplement portion to be consumed by the participating children, the family was also provided with other biscuits prepared with the supplement, but packaged differently, for the consumption of other family members. For compliance to be assessed, parents or caregivers were instructed to collect the empty packages and unused products.

At the end of the study, the children in the control group and their families received a supplement supply for three months.

\section{Measurements}

Baseline data were collected by qualified nutritionists, nurses, or physicians. Height and weight measurements were carried out using standard methods. For weight measurement, a digital scale was employed, with $200 \mathrm{~g}$ of the clothing weight of each participant being subtracted. Children's height was measured with a stadiometer. Z-score values to estimate low weight-for-age (WAZ), stunting (height-for-age [HAZ]), and wasting (weight-for-height [WHZ]) were calculated according to World Health Organization reference standards. ${ }^{26-31}$

Physicians evaluated the presence of severe acute infections (fever, diarrhea, acute cough, rhinorrhea), clinical symptoms of vitamin A deficiency (xerophthalmia) and iodine deficiency (visible goiter). Children with symptoms of acute infection or clinical signs of micronutrient malnutrition were referred to health centers or hospitals.

Questionnaires were used to obtain information on socioeconomic status, food consumption, intake of fortified foods and dietary supplements, child's age, gender, family size, and location.

Follow-up data related to weight and height were collected four, six and 12 months after starting the intervention. The children underwent physical examinations and anthropometric measurements, including weight and height. All of them were monitored for 12 months, even if they decided to stop consuming the dietary supplement or were withdrawn from the study. Legal guardians were interviewed about consumption of fortified and non-fortified foods and dietary supplements, acceptance of the study-evaluated dietary supplement, compliance with the intervention and adverse events. Children safety was assessed monthly by adverse events and serious adverse events monitoring. Serious adverse events were reported immediately to the region coordinator and to the project leader. Children with any acute gastrointestinal condition (i.e., diarrhea, abdominal distention or pain), respiratory distress, impaired consciousness, or hospitalization for any reason had to discontinue the consumption of the supplement until the condition resolved or until the doctor approved.

\section{Ethical aspects}

The protocol was approved by the Ethics and Research Committee of the Autonomous University of 
the State of Mexico. Parents or legal guardians were informed on the purpose of the study, its procedures, and possible benefits and risks. Those who agreed to participate signed a written informed consent form prior to the selection process and received a copy of the signed document. For parents or legal guardians without reading and writing skills, a community representative witness was present when the parent or guardian understood the content and applied one fingerprint to the consent form. All participants were free to withdraw from the study at any time (the research is registered at Clinical Trials with identifier NCT02572258).

\section{Data handling}

A 12-month incidence of moderate malnutrition of 17 and $26 \%$ was considered for the RUSF and nonRUSF groups, respectively, with an alpha value of 0.05 and power of $90 \%$. With this information, a sample size of 872 subjects was estimated. ${ }^{32}$

Patients with $<60 \%$ of compliance with the consumption of the biscuits were considered non-adherent. Adherence was evaluated by the number of biscuits consumed per month. ${ }^{33}$

Differences in the percentage of children with moderate acute malnutrition ( $\mathrm{WHZ}>-3$ and $\leq-2)$ or mild acute malnutrition resolution ( $\mathrm{WHZ}>-1$ and $<1$ ) between groups were evaluated using Cox proportional hazards models. Between-group differences in growth z-scores at four, six, and 12 months were assessed using an analysis of covariance (ANCOVA) adjusted for the respective baseline values. Intergroup differences in terms of adverse events were assessed using the chi-square test. Intent-to-treat (ITT) and per-protocol (PP) analyses were carried out. In all cases, a $p$-value $\leq 0.05$ was regarded as indicative of statistical significance.

\section{Results}

Participants' demographics and other baseline characteristics are shown in table 1.

In comparison with the non-RUSF group, the RUSF group predominantly consisted of male children (53\% vs. $46 \% ; p=0.065)$, and were younger ( $39 \pm 10$ vs. $43 \pm 10$ months; $p<0.001)$, shorter $(90 \pm 7$ vs. $93 \pm$ $7 \mathrm{~cm} ; p<0.001)$ and had lower body weight $(11.4 \pm$ 1.7 vs. $12.1 \pm 1.7 \mathrm{~kg} ; \mathrm{p}<0.001$ ).

Similarly, in comparison with the non-RUSF group, RUSF-g children had a HAZ closer to moderate chronic malnutrition $(-1.89 \pm 0.056$ vs. $-1.64 \pm 0.059$; $p=0.003$ ) and a WAZ within the parameters of moderate malnutrition $(-2.04 \pm 0.036$ vs. $-1.87 \pm 0.040 ; p$ $<0.001)$. WHZ was similar between both groups $(-1.40$ \pm 0.014 vs. $-1.37 \pm 0.015 ; p=0.167)$. RUSF-g children drank milk less frequently on a weekly basis than nonRUSF-g children (median and $25^{\text {th }}-75^{\text {th }}$ percentiles, 5 and $2-7$ vs. 7 and $3-7, p<0.001$ ).

As for the legal guardians, in comparison with the non-RUSF group, in the RUSF group there was a lower number of Spanish speakers (79 \% vs. $97 \%$; $p<0.001$ ), or had $\leq 10$ years of education (84\% vs. $74 \% ; p<0.001)$. More RUSF-g participants' families had $\geq 5$ children than those of the non-RUSF-g members (13 vs. $7 \%$; $p=0.021$ ).

During the first semester, 63,34 and $3 \%$ of RUSF-g families showed $\geq 60,<60$ and $0 \%$, respectively, adherence to the consumption of the biscuit. In the second semester, these adherence values changed to 43,42 and $15 \%$, respectively (Table 2).

Regarding the development of moderate malnutrition, no comparisons between groups were made, since only one case occurred. When mild acute malnutrition resolution was analyzed based on WHP at one year of follow-up in the intent-to-treat analysis, RUSF-g vs. non-RUSF-g children showed resolution rates of 68.7 vs. $52.1 \%$, respectively (direct increase of $16.6 \%$ and relative increase of $31.9 \%$ for RUSF-g). The Cox proportional hazards analysis adjusted for baseline $\mathrm{WHZ}$ showed a hazard ratio $(\mathrm{HR})$ of 1.25 , with $95 \%$ confidence interval $(\mathrm{Cl})=1.02-1.52$ $(p=0.026)$ for RUSF-g. With the per-protocol analysis, in the RUSF group with an adherence $\geq 60 \%$ during the first semester, mild acute malnutrition reduction was observed to be $77.2 \%$ (direct increase of $25.1 \%$ ) in comparison with $52.1 \%$ for non-RUSF-g, with $\mathrm{HR}=1.48(95 \% \mathrm{Cl}=1.21-1.83, \mathrm{p}<0.001)$; during the second semester, the resolution rate reached $82.2 \%$ (direct increase of $30.1 \%$ ), with $\mathrm{HR}=1.56$ (95\% Cl $=1.25-1.96, p<0.001)$ (Table 3).

WAZ mean difference between RUSF-g and nonRUSF-g was clinically relevant and statistically significant at four months $(-1.19 \pm 0.026$ vs. $-1.32 \pm 0.03$, $p=0.002)$, six months $(-0.83 \pm 0.03$ vs. $-1.02 \pm 0.04$, $p<0.001)$, and 12 months $(-0.44 \pm 0.03$ vs. $-0.58 \pm$ $0.04, p=0.008)$. In turn, HAZ mean difference was relevant and significant only at 12 months (Table 4):

- Four months, $-1.07 \pm 0.02$ vs. $-1.07 \pm 0.02$, $p=0.912$.

- Six months, $-0.76 \pm 0.03$ vs. $-0.82 \pm 0.03$, $\mathrm{p}=0.189$. 
Table 1. Participants' baseline and demographic characteristics

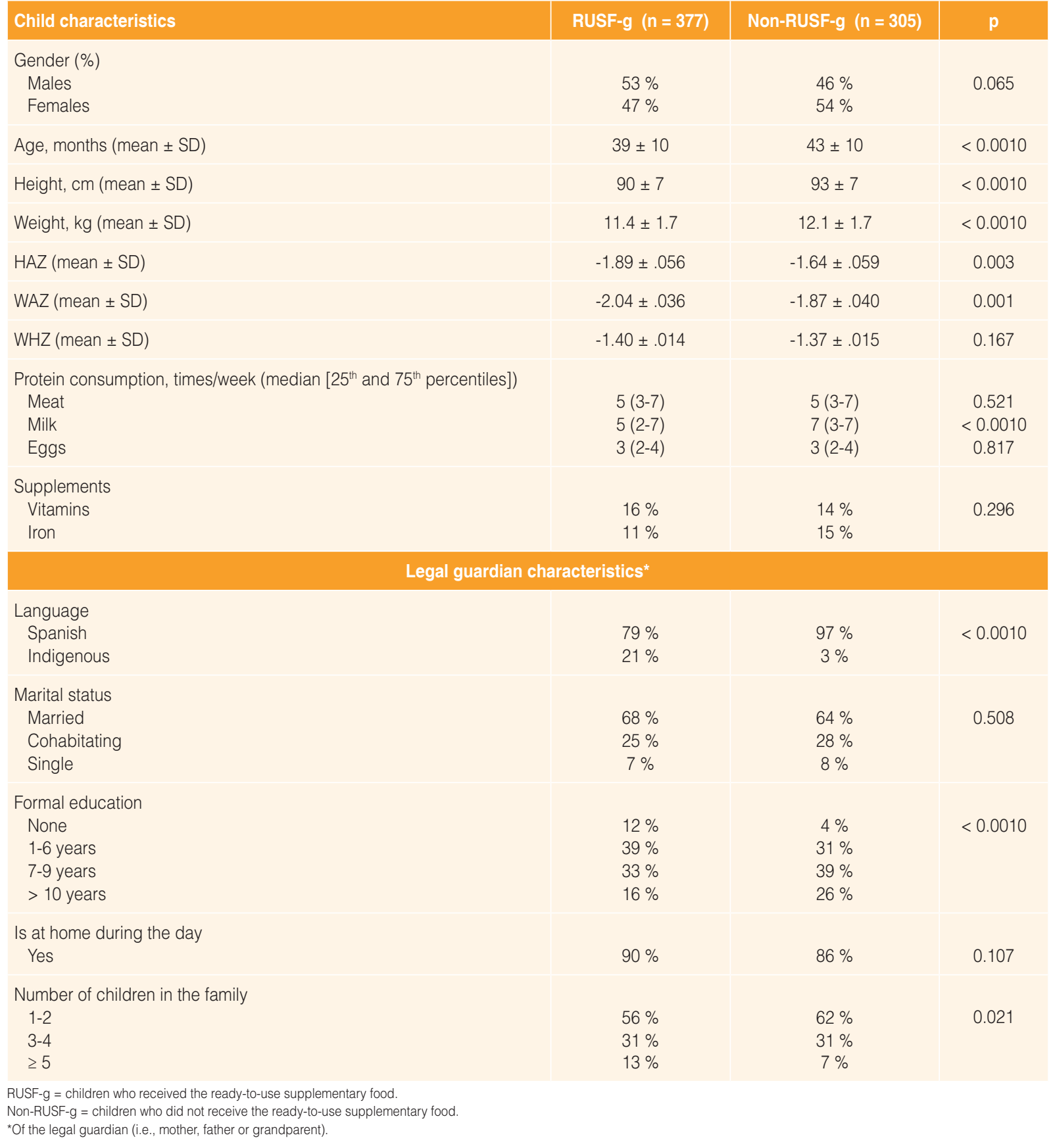

Table 2. Degree of adherence to consumption of the ready-to-use supplementary food biscuits in the intervention group

\begin{tabular}{|l|c|c|}
\hline \multirow{2}{*}{ Degree of adherence } & \multicolumn{2}{|c|}{ Period } \\
\cline { 2 - 3 } & First semester & Second semester \\
\hline$\geq 60 \%$ & $63 \%$ & $43 \%$ \\
\hline$<60 \%$ & $34 \%$ & $42 \%$ \\
\hline None & $3 \%$ & $15 \%$ \\
\hline
\end{tabular}

- Twelve months, $0.02 \pm 0.04$ vs. $-0.11 \pm 0.05$, $p=0.029$.

\section{Discussion}

The study suggests that RUSF daily consumption for one year, at an individual dose of four biscuits -equivalent to $250 \mathrm{kcal}, 6 \mathrm{~g}$ of protein, $12 \mathrm{~g}$ of lipids and 
Table 3. Cox proportional hazards analysis for mild acute malnutrition correction (WHZ)

\begin{tabular}{|c|c|c|c|c|}
\hline \multirow[t]{2}{*}{ Type of analysis } & \multicolumn{4}{|c|}{ Amelioration } \\
\hline & RUSF-g & Non-RUSF-g & $\operatorname{HR}(95 \% \mathrm{Cl})^{*}$ & $p^{*}$ \\
\hline Intent-to-treat analysis, n & 259/377 (68.7 \%) & $159 / 305$ (52.1 \%) & 1.25 (1.02 to 1.52$)$ & 0.026 \\
\hline $\begin{array}{l}\text { Per-protocol analysis } \\
\quad \geq 60 \% \text { adherence first semester, } n \\
\geq 60 \% \text { adherence second semester }\end{array}$ & $\begin{array}{l}183 / 237(77.2 \%) \\
134 / 163(82.2 \%)\end{array}$ & & $\begin{array}{l}1.48(1.21 \text { to } 1.83) \\
1.56(1.25 \text { to } 1.96)\end{array}$ & $\begin{array}{l}<0.0010 \\
<0.0010\end{array}$ \\
\hline
\end{tabular}

Table 4. Effects of the ready-to-use supplementary food biscuits on children anthropometric measurements at 4, 6 and 12 months of intervention

\begin{tabular}{|c|c|c|c|}
\hline \multirow[t]{2}{*}{ Measurement } & \multicolumn{3}{|c|}{ z-score* } \\
\hline & $\begin{array}{c}\text { RUSF-g } \\
(\text { mean } \pm \text { SE) }\end{array}$ & $\begin{array}{l}\text { Non-RUSF-g } \\
(\text { mean } \pm \text { SE) }\end{array}$ & $\mathbf{p}^{\dagger}$ \\
\hline \multicolumn{4}{|l|}{ Weight-for-age } \\
\hline 4 months & $-1.19 \pm .026$ & $-1.32 \pm 0.03$ & 0.002 \\
\hline 6 months & $-0.83 \pm 0.03$ & $-1.02 \pm 0.04$ & $<0.0010$ \\
\hline 12 months & $-0.44 \pm 0.03$ & $-0.58 \pm 0.04$ & 0.008 \\
\hline \multicolumn{4}{|l|}{ Height-for-age } \\
\hline 4 months & $-1.07 \pm 0.02$ & $-1.07 \pm 0.02$ & 0.912 \\
\hline 6 months & $-0.76 \pm 0.03$ & $-0.82 \pm 0.03$ & 0.189 \\
\hline 12 months & $0.02 \pm 0.04$ & $-0.11 \pm 0.05$ & 0.029 \\
\hline \multicolumn{4}{|c|}{$\begin{array}{l}\text { RUSF-g = children who received the ready-to-use supplementary food. } \\
\text { Non-RUSF-g = children who did not receive the ready-to-use supplementary food. } \\
{ }^{*} \text { Z-score = Z-scores adjusted for their respective baseline } z \text {-scores. } \\
{ }^{+} \text {ANCOVA }\end{array}$} \\
\hline
\end{tabular}

$29.5 \mathrm{~g}$ of carbohydrates-, formulated with nutritionally rich foods such as oats, peanuts, milk and eggs and fortified with vitamins and minerals, promoted mild acute malnutrition recovery in up to $82.2 \%$ of RUSF-g children, in comparison with $52.1 \%$ of non-RUSF-g children ( $\mathrm{HR}=1.56[95 \% \mathrm{Cl}, 1.25-1.96], \mathrm{p}<0.001)$.

RUSF-g children reached a normal WAZ at six months $(-0.83 \pm 0.03)$, while this condition was reached at up to 12 months by those in the non-RUSF group $(-0.58 \pm 0.04)$. In addition, a greater recovery in height (HAZ) was observed at 12 months in RUSF-g children $(0.02 \pm 0.04$ vs. $-0.11 \pm 0.05, p=0.029)$. Although baseline cultural conditions were slightly different between both groups, they were in favor of the non-RUSF group.

Most previously conducted studies tested the effect of supplementary foods among children with moderate malnourishment, with a WHZ average increase of 0.28 in comparison with diet or standard therapy being reported, ${ }^{22}$ but high relapse rates are observed within the first year, which can be close to $50 \% .{ }^{23}$ Therefore, food supplementation programs with long-term follow-up are needed, even after children achieve moderate malnutrition remission (i.e., mild malnutrition). ${ }^{24}$ However, programs are limited by their higher complexity and cost. In Mexico, programs such as Progresa have shown the benefits of long-term community-oriented strategies. ${ }^{34}$ In this sense, our study addresses two important situations:

- Acute malnutrition resolution in children.

- Maintenance of the intervention for a prolonged period, which can help prevent future relapses and sequelae.

In our study, only one case of progression to moderate acute malnutrition occurred among 682 participating children. This discrepancy between estimated and observed results could be due to the use of information from previous studies carried out predominantIy in Africa, where populations exhibit a larger number of adverse components. For example, only $3 \%$ of mothers in a Nigerian study had some education vs. $92 \%$ in our population ${ }^{35}$ in addition to this, people in Nigeria have a high incidence of comorbidities, including human immunodeficiency virus infection. ${ }^{24}$

An adherence $\geq 60 \%$ has been regarded as a good point of reference to assess the effect of maneuvers and has been used in various pathologies. ${ }^{33}$ Our results agree with this, and show that the higher the adherence to RUSF consumption, the higher the percentage of recovery, which in the intent-to-treat analysis was as high as $68.7 \%$, and in the per-protocol analysis, $77.2 \%$ for the first semester in those individuals with an adherence $\geq 60 \%$, in whom, in the second semester, it was $82.2 \%$, in contrast with $52.1 \%$ for the non-RUSF group. The reported degree of adherence $(63 \%$ in the first semester and $43 \%$ in the second) suggests RUSF high acceptability, which 
Table 5. Associated comorbidities in children*

\begin{tabular}{|c|c|c|c|}
\hline Month & Comorbidity & RUSF-g & Non-RUSF-g \\
\hline \multirow[t]{3}{*}{1} & PIGE & $21 \%$ & $17 \%$ \\
\hline & URTI & $42 \%$ & $50 \%$ \\
\hline & Fever & $4 \%$ & $7 \%$ \\
\hline \multirow[t]{3}{*}{2} & PIGE & $9 \%$ & $11 \%$ \\
\hline & URTI & $29 \%$ & $32 \%$ \\
\hline & Fever & $6 \%$ & $4 \%$ \\
\hline \multirow[t]{3}{*}{3} & PIGE & $10 \%$ & $9 \%$ \\
\hline & URTI & $18 \%$ & $12 \%$ \\
\hline & Fever & $1 \%$ & $2 \%$ \\
\hline \multirow[t]{3}{*}{4} & PIGE & $6 \%$ & $4 \%$ \\
\hline & URTI & $10 \%$ & $7 \%$ \\
\hline & Fever & $2 \%$ & $2 \%$ \\
\hline \multirow[t]{3}{*}{5} & PIGE & $5 \%$ & $2 \%$ \\
\hline & URTI & $10 \%$ & $3 \%$ \\
\hline & Fever & $1 \%$ & $0 \%$ \\
\hline \multirow[t]{3}{*}{6} & PIGE & $3 \%$ & $1 \%$ \\
\hline & URTI & $6 \%$ & $3 \%$ \\
\hline & Fever & $1 \%$ & $0 \%$ \\
\hline
\end{tabular}

RUSF-g $=$ children who received the ready-to-use supplementary food. Non-RUSF-g = children who did not receive the ready-to-use supplementary food *The children were visited every 15 days, but only one associated condition was considered per month, according to its seriousness in the following order: lower respiratory tract infection (LRTI), probable infectious gastroenteritis (PIGE), upper respiratory tract infection (URTI), fever. Only one child had LRTI at month 9.

has the advantage of being ready to be consumed without the need to mix or prepare.

A clear reduction in comorbidities was also observed in both groups as follow-up progressed, which could be the result of the nutrition, health and hygiene education provided to both groups (Table 5). However, we cannot rule out the possibility that these benefits may have been magnified by the lack of reports from caregivers as follow-up time advanced. Similarly, it is important mentioning that no adverse events were associated with RUSF consumption. The diarrhea reported in the study was similar between groups, suggesting that it was not related to RUSF consumption.

Mexico has managed to widely disseminate programs throughout the country, such as Progresa and Un Kilo de Ayuda, which have shown nutritional benefits for the most vulnerable populations. We believe that this RUSF can contribute to said programs, given that it does not require preparation (which reduces the risk of contamination), has different flavors (well tolerated by children) and has a long shelf life, which allows its delivery to distant places of the country and storage for a reasonable period. Other studies should assess the effect of introducing this type of RUSF with high nutritional value in local stores within disadvantaged communities and evaluate whether it contributes to reduce undernourishment and improve children's health status.

\section{Conflicts of interest}

Mónica J. García-Vilchis, Brenda Salgado-Enríquez and María Martínez-Jaureguiberry are PepsiCo Inc. emplyees; however, the opinions expressed in this article are not related to the opinion or policies of that company.

\section{Funding}

This research was funded and supported by PepsiCo Inc.

\section{Ethical disclosures}

Protection of human and animal subjects. The authors declare that the procedures that were followed adhered to the ethical standards of the responsible human experimentation committee and were in agreement with the World Medical Association and the Declaration of Helsinki.

Confidentiality of data. The authors declare that they have followed the protocols of their work center on the publication of patient data.

Right to privacy and informed consent. The authors obtained informed consent from the patients or subjects referred to in the article. This document is in the possession of the corresponding author.

\section{References}

1. United Nations System Standing Committee on Nutrition [website]. USA: Sixth Report on the World Nutrition Situation; 2010.

2. Muller $\mathrm{O}$, Krawinkel M. Malnutrition and health in developing countries. CMAJ. 2005:173:279-286.

3. World Food Programme [website]. Italy: The state of food security and nutrition in the world 2018. Building climate resilience for food security and nutrition; 2018.

4. Black RE, Allen LH, Bhutta ZH, Caulfield LE, de Onis M, Mathers C, et al. Maternal and child undernutrition: global and regional exposures and health consequences. Lancet. 2008:371:243-260.

5. Harton S, Alderman H, Rivera JA. Copenhagen Consensus 2008 Challenge Paper Hunger and Malnutrition. 2008.

6. Investing on the future. A united call to action on vitamin and minera deficiencies. Global Report 2009. Canada: World Bank/United Nations Children's Fund/Micronutrient Initiative/Global Alliance for Improved Nutrition; 2009. 
7. International Conferences on Nutrition. Major issues for nutrition strategies [website]. Italy: Food and Agriculture Organization of the United Nations/World Health Organization; 1992.

8. Enriching lives: overcoming vitamin and mineral malnutrition in developing countries. USA: World Bank; 1994.

9. Black R. Micronutrient deficiency-an underlying cause of morbidity and mortality. Bull World Health Organ. 2003;81:79.

10. Rush D. Nutrition and maternal mortality in the developing world. Am J Clin Nutr. 2000;72:212S-240S

11. Ramakrishnan U. Prevalence of micronutrient malnutrition worldwide. Nutr Rev. 2002;60:S46-S52.

12. Walter T, de Andraca I, Chadud P, Perales CG. Iron deficiency anemia: adverse effects on infant psychomotor development. Pediatrics. 1989;84:7-17.

13. Maberly GF. Iodine deficiency disorders: Contemporary scientific issues. J Nutr. 1994:124:1473S-1478S.

14. Boyages SC, Collins JK, Maberly GF, Jupp JJ, Morris J, Eastman CJ. lodine deficiency impairs intellectual and neuromotor development in apparently-normal persons. A study of rural inhabitants of north-central China. Med J Aust. 1989;150:676-682.

15. West KP. Vitamin A deficiency disorders in children and women. Food Nutr Bull. 2003:24:78S-90S.

16. Brown $\mathrm{KH}$, Wuehler SE, Peerson JM. The importance of zinc in human nutrition and estimation of the global prevalence of zinc deficiency. Food Nutr Bull. 2001;22:113-125.

17. Country partnership strategy for the United Mexican States for the period FY2014-2019. USA: The World Bank; 2013

18. González-de Cossío T, Rivera JA, Gonzalez-Castell D, Unar-Munguía $M$, Monterrubio EA. Child malnutrition in Mexico during the last two decades: prevalence using the new WHO-2006 growth standards. Salud Publica Mex. 2009;51:S494-S506.

19. Juárez B, Gonzalez C. Food security \& nutrition in Mexico. Report number MX0043. Mexico: Global Agricultural Information Network; 2010.

20. Mundo-Rosas V, Rodríguez-Ramírez S, Shamah-Levy T. Energy and nutrient intake in Mexican children 1 to 4 years old. Results from the Mexican National Health and Nutrition Survey 2006. Salud Publica Mex. 2009:51:S530-S539.

21. Rivera-Dommarco JA, Cuevas-Nasu L, Gonzalez-de Cosío T, Shamah-Levy T, García-Feregrino R. Desnutrición crónica en México en el último cuarto de siglo: análisis de cuatro encuestas nacionales. Salud Publica Mex. 2013;55:S161-S169.

22. Lazzerini M, Rubert L, Pani P. Specially formulated foods for treating children with moderate acute malnutrition in low- and middle- income countries. Cochrane Database Syst Rev. 2013:CD009584.
23. Stobaugh $\mathrm{HC}$, Bollinger $\mathrm{LB}$, Adams SE, Crocker AH, Grise JB, Kennedy JA, et al. Effect of a package of health and nutrition services on sustained recovery in children after moderate acute malnutrition and factors related to sustaining recovery: a cluster-randomized trial. Am J Clin Nutr. 2017:106:657-666.

24. Trehan I, Banerjee S, Murray E, Ryan KN, Thakwalakwa C, Maleta KM, et al. Extending supplementary feeding for children younger than 5 years with moderate acute malnutrition leads to lower relapse rates. J Pediatr Gastroenterol Nutr. 2015;60:544-549.

25. Rivera JA, Habicht JP. Effect of supplementary feeding on the prevention of mild to moderate wasting in conditions of endemic malnutrition in Guatemala. Bull World Health Organ. 2002;80:926-932.

26. Management of moderate malnutrition in under-5 children by the health sector. Switzerland: World Health Organization.

27. A manual. Measuring and interpreting malnutrition and mortality. Italy: Center for Disease Control and Prevention/World Food Programme; 2005

28. World Health Organization [website]. WHO child growth standards and the identification of severe acute malnutrition in infants and children. Switzerland: World Health Organization/United Nations Children's Fund; 2009.

29. United Nations Children's Fund [website]. USA: Nutrition in emergencies: welcome.

30. Cogill B. Anthropometric indicators measurement guide. USA: Food and Nutrition Technical Assistance Project/Academy for Educational Development; 2003.

31. WHO Multicentre Growth Reference Study Group. WHO child growth standards: length/height for age, weight for age, weight for length, weight for height and body mass index for age: methods and development. Switzerland: World Health Organization; 2006.

32. Talavera JO, Rivas-Ruiz R, Bernal-Rosales LP. Tamaño de muestra. Rev Med Inst Mex Seguro Soc. 2013:5:S36-S41.

33. Graham DY, Lew GM, Malaty HM, Evans DG, Evans DJ, Klein PD, et al. Factors influencing the eradication of Helicobacter pylori with triple therapy. Gastroenterology. 1992;102:493-496.

34. Rivera JA, Sotres-Alvarez D, Habicht JP Shamah T, Villalpando S. Impact of the Mexican program for education, health, and nutrition (Progresa) on rates of growth and anemia in infants and young children: a randomized effectiveness study. JAMA. 2004;291:2563-2570.

35. Isanaka S, Nombela N, Djibo A, Poupard M, van Beckhoven D, Guerin PJ, et al. Effect of preventive supplementation with ready-to-use supplementary food on the nutritional status, mortality, and morbidity of children aged 6 to 60 months in Niger: a cluster randomized trial. JAMA. 2009;301:277-285. 


\section{Appendix}

\section{Appendix 1. Topics covered by the nutrition, health and hygiene education program}

\begin{tabular}{|c|c|c|}
\hline & Topic & Objective \\
\hline 1 & Training & $\begin{array}{l}\text { Explain the purpose of the study, compliance, test product shared use prevention, test products } \\
\text { proper storage and use. }\end{array}$ \\
\hline 2 & $\begin{array}{l}\text { National health weeks } \\
\text { importance }\end{array}$ & $\begin{array}{l}\text { Encourage the community to participate in National Health Weeks by providing detailed } \\
\text { information on when, where and what benefits will they receive. }\end{array}$ \\
\hline 3 & Anemia & $\begin{array}{l}\text { Explain the causes and consequences of anemia due to iron deficiency and how to treat and } \\
\text { prevent anemia in small children. }\end{array}$ \\
\hline 4 & Consequences of malnutrition & $\begin{array}{l}\text { Explain the causes and consequences of malnutrition, offering comprehensive guidance on how } \\
\text { to prevent it. }\end{array}$ \\
\hline 5 & $\begin{array}{l}\text { Recommended diet for } \\
\text { preschool children }\end{array}$ & $\begin{array}{l}\text { Explain the characteristics and provide detailed recommendations on the selection and quantity } \\
\text { of dietary guidance for children younger than } 5 \text { years. }\end{array}$ \\
\hline 6 & Healthy pregnancy & $\begin{array}{l}\text { To promote awareness on the importance of receiving medical care and provide } \\
\text { recommendations on food selection during this period. }\end{array}$ \\
\hline 7 & Breastfeeding & $\begin{array}{l}\text { Raising awareness of the importance and health benefits of breastfeeding during the first } 6 \\
\text { months of life. }\end{array}$ \\
\hline 8 & Early childhood stimulation & $\begin{array}{l}\text { Explain the relevance of early stimulation for children younger than } 5 \text { years, as well as the } \\
\text { inclusion of its positive impact on neural development. }\end{array}$ \\
\hline 9 & $\begin{array}{l}\text { El Plato del Bien Comer, } \\
\text { Mexican Food Guidelines }\end{array}$ & $\begin{array}{l}\text { Explaining the Mexican Food Guidelines and identifying the three main food groups in order to } \\
\text { promote healthy eating. }\end{array}$ \\
\hline 10 & Parasitosis & $\begin{array}{l}\text { To describe the causes and consequences of intestinal diseases and provide guidance on how } \\
\text { and when children should be given anti-parasitic treatment. }\end{array}$ \\
\hline 11 & Hygiene & $\begin{array}{l}\text { To provide information on the importance of having good hygiene practices everywhere in order to } \\
\text { avoid and prevent diseases. }\end{array}$ \\
\hline 12 & $\begin{array}{l}\text { Importance and consumption } \\
\text { of inorganic nutrients }\end{array}$ & $\begin{array}{l}\text { Explain the importance of consuming inorganic nutrients through a proper diet and their dietary } \\
\text { sources. }\end{array}$ \\
\hline 13 & $\begin{array}{l}\text { Vitamin } A \text { and its benefits for } \\
\text { health }\end{array}$ & Explain the importance of vitamin A consumption through a proper diet and its dietary sources. \\
\hline
\end{tabular}


Gaceta Médica de México. 2020;156

Appendix 2. RUSF biscuits nutritional composition

\begin{tabular}{|c|c|}
\hline Nutrients & Contents (per $50 \mathrm{~g}$ serving, four biscuits) \\
\hline Energy & 250 kcal (1046 kJ) \\
\hline Protein* & $6 \mathrm{~g}$ \\
\hline Lipids & $12 \mathrm{~g}$ (43 \% of total energy) \\
\hline Carbohydrates & $29.5 \mathrm{~g}$ \\
\hline Sodium & $161 \mathrm{mg}$ \\
\hline Potassium & $300 \mathrm{mg}$ \\
\hline \multicolumn{2}{|c|}{ Percentage of nutrition reference values per serving ${ }^{\dagger}$} \\
\hline Calcium & 200 mg (22.2 \%) \\
\hline Phosphorus & $150 \mathrm{mg}(22.6 \%)$ \\
\hline Magnesium & $50 \mathrm{mg}(20.2 \%)$ \\
\hline Iron & $8 \mathrm{mg}(47.1 \%)$ \\
\hline Zinc & $7 \mathrm{mg}(70 \%)$ \\
\hline Copper & $100 \mu g(15 \%)$ \\
\hline lodine & $90 \mu \mathrm{g}(90.9 \%)$ \\
\hline Vitamin A & $300 \mu \mathrm{g}(52.8 \%)$ \\
\hline Vitamin $D_{3}$ & $2 \mu g(20 \%)$ \\
\hline Vitamin $\mathrm{E}$ & $5 \mathrm{mg}(45.5 \%)$ \\
\hline Vitamin $B_{1}$ & $0.5 \mathrm{mg}(62.5 \%)$ \\
\hline Vitamin $\mathrm{B}_{2}$ & $0.5 \mathrm{mg}(59.5 \%)$ \\
\hline Vitamin C & $40 \mathrm{mg}(66.7 \%)$ \\
\hline Vitamin $B_{6}$ & 0.5 mg (53.8 \%) \\
\hline Vitamin $B_{12}$ & $1.2 \mu \mathrm{g}(57.1 \%)$ \\
\hline Folic acid & $160 \mu \mathrm{g}(42.1 \%)$ \\
\hline Niacin & 6 mg (54.5 \%) \\
\hline
\end{tabular}

